\title{
Progress on Milk Safety in Relation to Prion Protein
}

\author{
Feng Guan ${ }^{1}$, Juntao $\mathrm{Ai}^{2}$, Yuanyuan Luo ${ }^{1}$, Aichun $\mathrm{Xu}^{1}$, Jin $\mathrm{Zhao}^{1 *}$
}

\begin{abstract}
Transmissible spongiform encephalopathies (TSEs) belong to prion diseases that are invariably common fatal neurological disorders and affect humans and animals. Prion protein $(\mathrm{PrP})$ was regarded as the only infectious agent inprion diseases and much attention was focused on the safety of PrP in foodstuffs. In this review, theprogress on the safety of milk relation to PrP and transmission route of prion diseases through milk are reviewed, including the discovery, content, source and the risk assessment of PrP in milk and milk products. And some possible control ways were proposed, which might be of particular interest for the improvement of milk safety relation to $\operatorname{PrP}$ in dairy food.
\end{abstract}

\section{Introduction}

Transmissible spongiform encephalopathies (TSEs) affect humans and animals which most commonly known as prion diseases are invariably fatal neurological disorders. Prion diseases have emerged globally two hundred years ago as a significant threat to animal health and then human and prion protein (PrP) was believed to be the only causative agent of these diseases ${ }^{[1]}$ which included bovine spongiform encephalopathy (BSE) in bovine, sheep and goat scrapie, human classic and variant Creutzfeldt Jakob disease (vCJD) and so on. All of these diseases are characterized by the post translational misfolding of the host cellular isoform of the $\operatorname{PrP}\left(\mathrm{PrP}^{\mathrm{C}}\right)$ into an abnormal, infectious isoform $\operatorname{PrP}\left(\mathrm{PrP}^{\mathrm{Sc}}\right)$, which affecting the central nervous system (CNS) within a variety of mammal species and humans. BSE first appeared in 1986 in UK and soon it propagated in many European countries and others outside of Europe, ever involved to epidemic proportions with 1000 cases occurring per week in $1992^{[2]}$. Even more worrying was that the public health as food-meat transmission of BSE to human was known to be the cause of the $\mathrm{vCJD}^{[3]}$ and the infectivity of scrapie seemed to be higher compared to cattle BSE ${ }^{[4]}$. The mechanism of etiology of TSE has not been fully elucidated to date but PrP had been proved to be the only infectious agent, which plays a central role in the pathogenesis of these diseases ${ }^{[1,5]}$. Since then, $\operatorname{PrP}$ was regarded as a newly infectious agent that resulted in zoonosis in human and many animals, and much research attention was focused on this protein. As we all know, many evidences proved that the prion in milk from scrapie affected ruminates can transmit this disease, directly or through the presence of milk derived material in animal feed stuffs ${ }^{[6-9]}$. It also raised some concern with regard to the risk to humans of TSE exposure milk from ovine and cow.

In this article, the basic characteristics, physiological functions, the source and content of PrP in milk and its risk assessment were reviewed. The aim is to provide some references to the milk safety and processing and animal resistant breeding.

\section{PrP and Prion Diseases}

PrP is a membrane bound glycoprotein whose role in life had not fully elucidated. It has been proved that PrP played an important role in biological functions, such as trafficking of copper ions, yielding cellular antioxidative defense, cytoprotective activities, cell early embryogenesis, cell adhesion, signal transduction and regulation of apoptosis ${ }^{[10,11]}$ and so on. Furthermore, $\mathrm{PrP}^{\mathrm{C}}$ is a receptor for Amyloid-beta that results in human Alzheimer Disease ${ }^{[12,13]}$. The normal or $\operatorname{PrP}^{\mathrm{C}}$ is an apparently benign protein that is capable of mis-folding
Open Access

Review Article

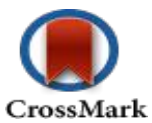

${ }^{1}$ China Jiliang University, College of Life Sciences, Hangzhou, Zhejiang 310018, China

${ }^{2}$ Beijing Vocational College of Agriculture, Beijing 10000, China

*Corresponding author: Jin Zhao, China Jiliang University, College of Life Sciences, Hangzhou, 310018, China, Tel: +86571-86835772; Fax: +86-57186914449;

E-mail: zhaojin@cjlu.edu.cn

Received Date: March 13, 2017

Accepted Date: July 18, 2017

Published Date: July 27, 2017

Citation: Zhao, J., et al. Progress on Milk Safety in Relation to Prion Protein. (2017) Int J Food Nutr Sci 4(2) : 81- 87.

Keywords: Prion protein (PrP); Milk and milk products; Safety; Risk assessment

DOI: $10.15436 / 2377-0619.17 .1420$ 
into a protease resistant conformation designated $\mathrm{PrP}^{\mathrm{Sc}}$. $\mathrm{PrP}^{\mathrm{C}}$ is a prerequisite for the development of TSEs as demonstrated by prion protein encoding gene (PRNP) knock-out mice being fully resistant to prion disease ${ }^{[14,15]}$. $\mathrm{PrP}^{\mathrm{Sc}}$ and $\mathrm{PrP}^{\mathrm{C}}$ had the same primary structure and different conformational structure. The two PrP conformations were significantly difference in physical and chemical characteristics. $\mathrm{PrPsc}^{\mathrm{Sc}}$ is extremely resistant to most of the chemical and physical processes that inactivate conventional viruses, and it does not evoke any detectable immune response or inflammatory reaction in host animals. Fortunately, there is an in vitro assay termed protein misfolding cyclic amplification (PMCA) can be used to detect $\operatorname{PrP}^{\mathrm{Sc}}$ from many animal tissues ${ }^{[16]}$. This method is a simple, sensitive and quick assay for identification of $\mathrm{PrP}^{\mathrm{Sc}}$ comparison of animal testing and immune-histochemistry methods.

The prion diseases have been found in many mammalian species except for above mentioned, as well as chronic wasting disease (CWD) in deer and elk, Gerstmann-Rtraussler Scheinker disease (GSS) and fatal familial insomnia (FFI) in humans. Human vCJD was believed to be transmitted from cattle or other animals via their derived food products ${ }^{[17]}$. There were experimental evidences including epidemiological and biological showed that the $\mathrm{PrP}^{\mathrm{Sc}}$ caused $\mathrm{vCJD}^{[3]}$. It was reported that the employment of prion contaminated gonadotropins, corneal transplantations, dura mater grafts and surgical instruments had resulted in more than 250 cases of iatrogenic CJD in the 1970 s with drastic implications for clinical practice ${ }^{[18]}$. And the excreta, urine and even infected soil had infectivity for prion diseases ${ }^{[19-21]}$. The oral route was considered to be the most plausible way of common infection, and the ruminant derived meat and bone meal (MBM) affected prion was regarded as the BSE source ${ }^{[17]}$. Therefore there is concern that the $\mathrm{PrP}^{\mathrm{Sc}}$ can be transmitted to humans by biological materials (i.e. meat products, milk, blood) from susceptible BSE animal species (mostly cows but possibly, sheep and goats). The knowledge of food safety in relation to PrP indicated that the removal of the specified risk materials (SRM) from the meat products would result in a major reduction of the BSE exposure risk associated with meat foodstuffs ${ }^{[22]}$. So, the detection and control of $\mathrm{PrP}^{\mathrm{Sc}}$ resource is a key procedure in the prevention for prion diseases, especially for the food chain. A ban on the use of meat and bone meal in the cattle feed ultimately resulted in a progressive decline of the BSE epidemic $^{[23]}$. In recent years, risk assessment was carried out by EU for many animal tissues from cattle, sheep and goat to reduce the risk for BSE in food chain ${ }^{[22,24]}$.

Milk is an important component of the human diet as well as animal feeds. Given the BSE epidemic in the UK and the continuing occurrence of low numbers of BSE cases, if prion was secreted within milk it seemed most probably that considerable numbers of people have been exposed to the BSE agent through milk ingestion. What is certain is that the pathogenesis of prion diseases resulting from repeated low dose exposure ${ }^{[25]}$. Considering these results, the detection of PrP in ruminant milk and milk products suggested that it had a potential risk to human for prion diseases ${ }^{[26,27]}$. Therefore, much attention was given to the safety of milk and milk products after the detection of PrP in them.

\section{Milk and the Source of PrP}

$\mathrm{PrP}^{\mathrm{C}}$ is usually located on the extracellular surface, at- tached via glycosylphosphatidyl inositol (GPI) anchor domain to cholesterol and sphingolipid rich membrane micro domains called lipid rafts. It is abundant in central nervous system (CNS) tissue, but it is also in non-neuronal tissues such as mammary gland at lower concentration. It was demonstrated for the first time that the existence of soluble $\operatorname{PrP}^{\mathrm{C}}$ and $\operatorname{PrP}^{\mathrm{C}}$ fragments in fresh ovine milk as well as in commercial homogenized and pasteurized bovine milk in 2007 ${ }^{[27]}$. The $\operatorname{PrP}^{\mathrm{C}}$ existed in fresh and commercially processed bovine milk, which had a near full length as $\mathrm{PrP}^{\mathrm{C}}$ species in $\mathrm{CNS}$, although they were absent or below the detection limits in powdered milk ${ }^{[27]}$. With this finding, it promoted a number of questions: could such $\operatorname{PrP}^{\mathrm{C}}$ species be converted into $\mathrm{PrP}^{\mathrm{Sc}}$, could similar secretary pathways result in the occurrence of exocrine $\operatorname{PrP}^{\mathrm{Sc}}$ and therefore did milk play a role in prion diseases transmission? Of course, we now know that at least part of prion diseases can be transmitted by affected ruminant milk, such as in sheep, goat and cow. The prion was detected in milk from ewes incubating natural scrapie and animal testing had been shown that the prion could contribute to the animal TSE transmission process ${ }^{[28]}$. In the next year, related studies proved that prion was secreted in milk from clinically and scrapie subclinical infectious sheep and the prion could be as seed for PMCA detection ${ }^{[25,29]}$.

In general, there are two known major routes through which proteins are secreted into milk. Firstly, it can be transmitted with the cell shedding pathway. A certain number of cells can be found in the fresh milk which secretes from healthy dairy animals including cow and sheep, the number of cells is lower than $2 \times 10^{5} \mathrm{~mL}^{-1}$, which is adapt to animal mammary glands autoimmune $^{[29]}$. The number of $98 \%$ cells in milk comes from white blood cells including macrophages, leucocyte neutrophil and lymphocyte, and others deciduous epithelial cells located on the mammary tissue ${ }^{[26,30]}$. If animals were under inflammatory conditions, the total number of immune cells would increase in milk, it might be possible that infectious $\mathrm{PrP}^{\mathrm{Sc}}$ was also passing through and reaches the milk. Recent studies showed that $\operatorname{PrP}^{\mathrm{C}}$ was selectively localized in mammary gland epithelial cells and expressed largely at the basolateral cell surface that had active secretion ${ }^{[31]}$. $\mathrm{PrP}^{\mathrm{Sc}}$ was shed into milk from clinically normal, scrapie exposed animals, and it could be detected using serial protein misfolding cyclic amplification (sPMCA) at least 20 months before clinical onset ${ }^{[29]}$.

Secondly, the proteins can be transmitted into milk by cells secretion. The protein exocytotic secretion produced epithelial cells within mammary gland, and the secretion was associated with milk fat globules, the vesicular transcytosis of serum- and stromal cell-derived proteins as well as through a paracellular transport system that was responsible for the secretion of plasma components and leukocytes ${ }^{[27]}$. Onecase demonstrated that bovine $\mathrm{PrP}^{\mathrm{C}}$ was selectively localized in mammary gland epithelial cells and expressed largely at the basolateral cell surface that showed active secretion ${ }^{[31]}$. The existence of $\operatorname{PrP}^{\mathrm{C}}$ in mammary gland cells supported the hypothesis that the apocrine secretion mode of milk fat globules was a major transporting way into the milk ${ }^{[26]}$.

In addition, milk processing had little or no effects on the structure of $\operatorname{PrP}^{\mathrm{C}}$ and $\mathrm{PrP}^{\mathrm{Sc}}$ due to their specific physical and chemical characteristics, except for diluting and decreasing their concentrations. Certainly, the characteristics and presence of PrP increased the milk risk to ingestion. PrP were also existed in full 
fat milk, semi skimmed and skimmed bovine milk at reduced levels compared with unprocessed milk. While baby formula milk contained considerably lower levelof $\operatorname{PrP}^{\mathrm{C}}$ which were below the detection limits ${ }^{[27]}$.

\section{Milk and the Content of PrP}

The milk and milk products represent a major nutrition component in our life, so it seems of particular important to analyze whether the PrP is to be present in milk and milk products. The detection and safety assessment of PrP in milk were given much attention in recent years because of its risk has a directly strong relationship with human health. Considering of the existence of PrP in blood and skeletal tissues, it was supposed that there would had PrP in milk which comes from the blood cell and mammary gland epithelial cells. But limited lack of sensitive tools for monitoring the lower concentration of PrP, there no PrP had been detected in milk because the high concentration of total protein (about $40 \mathrm{mg} / \mathrm{ml}$ ) and high amount of lipids (about $35 \mathrm{mg} / \mathrm{ml}$ ). Thus it was believed that $\operatorname{PrP}^{\mathrm{C}}$ and $\operatorname{PrP}^{\mathrm{Sc}}$ only existed in cellular fraction from blood, but not in milk ${ }^{[26]}$.

With the development of detection technologies for protein, several assays including immune-histochemistry, Western Blot, ELISA and immunoprecipitation and others were used to detect PrP with qualitative and quantitative in milk and even mammary gland cells. In view of a recent study showing evidence of prion replication in the mammary gland of sheep with scrapie and mastitis, the researchers concluded that the presence of normal prion in milk implied a possibility that milk from animals with TSEs served as a source of infectious agent ${ }^{[26]}$. Using these assays, it has been proved that the expression pattern of PrP in milk had a species-specific manner in different animals. The contents of $\mathrm{PrP}^{\mathrm{C}}$ had a significantly difference in bovine, ovine and caprine mammary gland, skimmed milk, acid whey and cream. The relative highest expression level associated with the cream fraction, and the PrP in milk had similar full length and structural characteristics as in nervous tissue ${ }^{[27,32]}$. Comparison with brain-derived $\mathrm{PrP}^{\mathrm{C}}$, prion in milk displayed an increased electrophoretic mobility in ovine milk, and it had been proved that ovine and goat milk contained $\operatorname{PrP}^{\mathrm{C}}$ in all fractions with an additional truncated form at $12 \mathrm{kD}$ by Western blot. This truncated PrP isoform was the predominate one in goat acid whey ${ }^{[27]}$.

Franscini et $\mathrm{al}^{[26]}$ developed an adsorption matrix termed Alicon PrioTrap for detecting milk PrP, which can bind to PrP with high specificity and affinity. This method could help detecting $\operatorname{PrP}^{\mathrm{C}}$ in milk from humans, cows, sheep and goats. After treating with this technology, $10 \mathrm{~mL}$ milk was detected with Western Blotting, which from cow, sheep, goat and human, respectively. The results showed that there had three $\operatorname{PrP}^{\mathrm{C}}$ isoforms in cow milk with an apparent molecular mass of about $34 \mathrm{kD}$, $30 \mathrm{kD}$ and $27 \mathrm{kD}$ corresponding to diglycosylated, monoglycosylated and unglycosylated $\mathrm{PrP}^{\mathrm{C}}$, respectively. About the same distribution of $\mathrm{PrPC}^{\mathrm{C}}$ isoforms were observed in sheep, goat and human milk, although the total amount of native $\operatorname{PrP}^{\mathrm{C}}$ significantly differed between the species. The studies of quantitative investigation showed that the total concentration of $\mathrm{PrP}^{\mathrm{C}}$ in fresh cow milk could be estimated to be about $200 \mathrm{pg} / \mathrm{mL}$. The relative amount of $\operatorname{PrP}^{\mathrm{C}}$ in fresh milk in sheep, goat and humans containing about $1 \mathrm{ng} / \mathrm{mL}, 40 \mathrm{pg} / \mathrm{mL}$ and $<10 \mathrm{pg} / \mathrm{mL}$, respectively. The relative ratio of $\operatorname{PrP}^{\mathrm{C}}$ in sheep, cow, goat and human fresh milk was estimated at 100:20:4:1 ${ }^{[26]}$. The absolute amount of $\operatorname{PrP}^{\mathrm{C}}$ dif- fered between the species and the concentration differed from $\mu \mathrm{g} / \mathrm{L}$ range in sheep to $\mathrm{ng} / \mathrm{L}$ range in human milk. $\operatorname{PrP}^{\mathrm{C}}$ was also found in homogenized and pasteurized off-the-shelf milk, and even in ultrahigh temperature treatment milk that only partially diminished endogenous $\mathrm{PrP}^{\mathrm{C}}$ concentration. The concentration of $\operatorname{PrP}^{\mathrm{C}}$ in pasteurized and ultrahigh temperature treated milk was reduced comparison with fresh milk, but the $\mathrm{PrP}^{\mathrm{C}}$ could be detected clearly, their contents were equal to goat fresh milk ${ }^{[26]}$.

\section{Milk and the Transmission of $\operatorname{PrP}^{\mathrm{Sc}}$}

The increasing awareness and involvement of consumers in milk and milk products safety issues, strongly stimulated by the BSE crisis in Europe and other states, which had resulted in the introduction of Food Standards Agencies in several countries. Over the last 30 years, scientific groups, risk assessment agencies and public health organizations have debated the TSE transmissible risk for milk and milk products. In 1997, the Scientific Steering Committee of the European Commission has categorized risk materials in 4 classes. Colostrum, milk and mammary gland tissues have been classified in category 4 , i.e. "infectivity not detected". In 2000 investigations started in Great Britain to test milk fractions, especially the fraction of somatic cells, for the possible occurrence of prions, using newly developed and highly sensitive methods, results showed no indications of a BSE transfer via the milk to the calves ${ }^{[33]}$. Tyshen$\mathrm{ko}^{[34]}$ reported a risk assessment for milk and milk products from Canadian infected dairy cows, the evidence indicated that the risk of the consumption of milk was negligible. And available epidemiological and bioassay data have not provided evidence for milk to be as an infectious agent before 2006 because of the lack of sensitive tools for detecting the infectious PrP agent. The detection and identification of $\mathrm{PrP}^{\mathrm{Ps}}$ in milk from infected sheep could be as a source for scrapie that acted as a trigger for a series of discussion in the world since $2006^{[26]}$. The transmission risk from milk and milk products has been debated in the scientific and public for at least twenty years.

The studies on risk from milk and milk products relation to PrP were taken out since 1960s. In 1995, Taylore et $\mathrm{al}^{[35]}$ reported that milk from BSE affected cows was given to mice $(n=275)$ by drinking (i.e. average consumption of 300 $\mathrm{mL}$ per mouse for a total of 40 days) or combined intracerebral $(0.02 \mathrm{~mL})$ and intraperitoneal $(0.1 \mathrm{~mL})$ routes, but no clinical disease and no neuropathological lesions were found after a period of two years observation, and no evidence was found in experimental mice which were transmitted with milk affected $\mathrm{PrP}^{\mathrm{Ps}}$. A few other studies have investigated the BSE infectivity by challenge of experimental animals with milk concentrated from BSE affected ewes to calves, but no infectious evidences were found, so the milk and dairy products were taken for safety for a long time since then ${ }^{[8]}$. In addition, the different risk tissues from TSE susceptible animals were categorized in different classes by the European Commission and WHO for medicinal products. Milk, colostrum and the mammary gland tissues have been classified in the category of no detectable infectivity, or to say these products in relation to BSE was negligible, a secondary contamination of milk was virtually excluded ${ }^{[36]}$. Furthermore, no affected people were found after a long time survey of drinking milk, it was considered that milk and milk products had no transmissibility ${ }^{[37]}$. In the later several years since 1995, data from many studies further supported the conclusions concerning 
the safety of milk. No BSE cases had been occurred out of off spring born to BSE-infected cows. The known evidence from other animals and humans suggested that milk did not transmit prion diseases. Because of prion infectivity had never been found in milk and milk products originating from TSE-affected ruminant flocks before 2006 year, the milk and milk products were not unrestricted into the animal and human food chain ${ }^{[38]}$. Under these conditions, the risk of milk and milk products in relation to BSE was negligible for a long time although BSE had been found in several animal species during this period. Data from epidemiological studies as well as from bioassay available before 2006 did not indicate the existence of infectious prion in any milk components, including the mammary gland, milk and colostrum as well as somatic milk cells of clinically BSE affected $\operatorname{cows}^{[38]}$. Based on all the achievements, the major authorities in the world at that time had, following consideration of the results of transmission and epidemiological studies, announced that milk was safe to prion diseases ${ }^{[39]}$. The authorities included the world health organization, the office international des epizooties, the European commission and the UK spongiform encephalopathy advisory committee. In addition, the United States department of agriculture had placed no restriction on the importation of milk from BSE affected countries. It followed that milk products were also regarded as safe provided that they contained no other animal derived product for which a favorable risk assessment has been completed. All the authorities regarded no epidemiological evidences to support milk being a source of BSE infectivity at that time ${ }^{[39]}$. On the other hand, scrapie and BSE were far more widely disseminated in many states and animal species in this period ${ }^{[40]}$. And in the later years, many more sheep were infected with scrapie, which resulted in the scientists doubted that the BSE affected sheep with mastitis could transmit the prion diseases through unknown pathway ${ }^{[41]}$. A epidemiological study has found an increased incidence of scrapie in the offspring of scrapie-affected ewes, which is suggestive of material transmission, but not know what happen? ${ }^{[42]}$. Furthermore, ovine PrPSc seemed to be present in lymphoid structures with mastitis affected mammary glands in scrapie sheep ${ }^{[4]}$. Under these conditions, the safety of milk was again given much attention with the finding of milk $\operatorname{PrP}^{\mathrm{C}}$ and the evidences that it could be transmitted into $\mathrm{PrP}^{\mathrm{Sc}}$ from BSE affected cow to humans and resulted in $\mathrm{vCJD}^{[3,43,44]}$. In fact, before the finding of these facts, the European food safety authority had claimed that TSE infectivity in milk from small ruminants could not completely be ruled out $^{[38]}$. Considering of a relative study showed that prion replication occurred in the mammary gland with mastitis within scrapie infected sheep, the foundation of $\operatorname{PrP}^{\mathrm{C}}$ in milk implied the possibility that milk from TSE infected animals could be served as source for $\mathrm{PrP}^{\mathrm{Sc}}$. And it was proposed that this replication could be taken out in sheep mammary gland, because $\operatorname{PrP}^{\mathrm{Sc}}$ was located in mammary glands ${ }^{[9,41]}$. In the later, experimental lambs with high susceptible PRNP genotypes (VRQ/VRQ) were fed with milk from scrapie affected ewes, then PrPSc was detected in lymphoid follicles and distal ileum in these lambs, although they had no clinical symptoms, 15 live lambs in experimental group were positive for $\mathrm{PrP}^{\mathrm{Sc}}$ after seven months, whereas $\operatorname{PrP}^{\mathrm{Sc}}$ was not detected in the 14 control flock. Furthermore, some of the control lambs were detected $\mathrm{PrP}^{\mathrm{Sc}}$ accumulation at time 199 days after mixing with experimental lambs ${ }^{[45]}$. The evidence sounded a warning against the safety of milk and milk products. In the later, opinion of the scientific panel on biological hazards on the human and animal exposure risk related to TSEs considered that the milk was an agent could be transmitted prion diseases ${ }^{[46]}$. In 2014, the milk feeding experiment provided ample evidence that milk from scrapie-affected sheep resulted in a high transmission in sheep and both colostrum and milk transmitted scrapie, even if as little as 1.5 liters of colostrum was fed ${ }^{[6]}$. The same as sheep milk, the milk from goat with scrapie could transmit scrapie to sheep lambs with both VRQ/VRQ and ARQ/ARQ genotypes ${ }^{[7]}$. To date, for all we know, the scrapie affected milk can not only transmit the scrapie within sheep, goat and even crossed species, but also the diseases can be transmitted vertically and laterally through milk ${ }^{[7,9,45,47,48]}$. Other studies had proved the fact that scrapie could be spread via milk, which indicated that the risk may be higher than previous thought. It was reported that the detection of infectivity in colostrum and milk could be done from sheep incubating natural scrapie before several months clinical onset $^{[8]}$. Prion infectivity was present in milk and colostrum, especially for lymph proliferative chronic mastitis, and even those displaying lesion-free mammary gland. In all tested infectivity milk fractions, cell pellet, casein whey and cream were regarded as with higher transmission rate and/or shorter incubation peri$\mathrm{od}^{[8]}$. One experimental case demonstrated that the ingestion of as little as 1 to 2 liters of milk from scrapie and lympho follicular mastitis affected sheep could cause prion infection in sheep lambs with middle PRNP susceptibility ARQ/ARQ genotype at an attack rate of $86 \%{ }^{[9]}$. Interestingly, it suggested that species barrier would decrease the transmission risk in many animal species. Furthermore, rearing type had effects on transmission rate, i.e. the lambs fed artificially had lower risk than that of material feeding ${ }^{[49]}$. Update now, it is certain that the milk and even many milk products will be infective agent for scrapie and other prion diseases, in species and/or even different species.

\section{Conclusions and Prospects}

Together with these recent progresses on infectious prion in milk, the evidences indicated that there has a risk of prion diseases could be spread to other animals through dietary exposure to milk and milk products. World milk production ranged around 500 million tons a year, which contribute $13 \%$ to the world protein supply for humans. The studies to determine the extent of infectious prion enter our global food supply would be worthwhile and important for risk assessment. Before fresh milk reached the consumer, it was usually homogenized to reduce fat particle size in order to increase digestibility of the milk and heated. But the procedure treating for milk could not eliminate or destroy endogenous $\mathrm{PrP}^{\mathrm{C}}$ and $\mathrm{PrP}^{\mathrm{Sc}}$ except for a partial reduction of the concentration, included pasteurization and ultrahigh temperature treatment. Under these conditions, the risk assessment of PrP in milk and milk products is very important for food safety. The potential BSE risk for milk and milk products needs to be evaluated by risk assessment. Today, the existence of PrPC and PrPSc had been detected in fresh milk as well as in mammary gland epithelial cells in ovine and cow; the experimental cases showed the TSE could be transmitted via milk affected scrapie. Unfortunately, as we have known that, the incubation period of BSE averages $4 \mathrm{~d}$ to years, animals are infected with the BSE long before they manifest any symptoms. When infected symptom-free animals are milked, their milk is mixed in collection 
tanks with milk from healthy animals. If the $\mathrm{PrP}^{\mathrm{Sc}}$ is present in milk, it could theoretically contaminate the whole collection tank.

But meanwhile, there were a few control measures which had a major effect on the control of BSE, including removing the materials with the highest infectious load from food and feed ${ }^{[50]}$. The combination of one and more enforced control measures could be able to reduce transmission levels or risk by $99 \%$ based on a recent quantitative analysis. The BSE and other prion diseases had been effectively controlled by food inspection and resistant animal breeding with the quarantine technology and molecular biology development ${ }^{[51]}$. The FDA had prohibited the use of animal feeds given to ruminant and required the process to ensure that ruminant feed did not contain the prohibited mammalian tissue since 1997. In the next several years, the milk from BSE infected cattle had been banned to enter human food chain. Although it was supposed that the risk from milk did appear to be much smaller than from eating beef or cattle organ tissues.

In addition to milk must be sourced from healthy animals, the PrP and other specific proteins can be inspected, detected, regulated and even separated with modern biotechnologies in milk procedure ${ }^{[26,52,53]}$. For example, the endogenous PrPC could be completely eliminated after the second treatment with AliconPrio Trap ${ }^{[28]}$. On the other hand, resistant breeding is another method for milk safety. The resistant animals (sheep and cow) can be selected according to the polymorphisms of PRNP ${ }^{[54,55]}$. These methods will ensure of providing more safety milk in our life.

Acknowledgements: We gratefully acknowledge financial support from the Science and Technology Department of Zhejiang for public welfare Technology Application Research (2016C37114 and 2017C32081), the National Natural Science Foundation of China (No. 31672394 and 31360540), and Science and Technology Programe of Zhejiang Food and Drug Administration (No.2014020).

\section{References}

1. Prusiner, S.B. Novel proteinaceous infectious particles cause scrapie. (1982) Science 216: 136-144.

Pubmed | Crossref $\mid$ Others

2. Collinge, J., Clarke, A.R. A general model of prion strains and their pathogenicity. (2007) Science 318(5852): 930-936.

Pubmed $\mid$ Crossref $\mid$ Others

3. Will, R.G., Ironside, J.W., Zeidler, M., et al. A new variant of Creutzfeldt-Jakob disease in the UK. (1996) Lancet 347(9006): 921925.

Pubmed $\mid$ Crossref $\mid$ Others

4. Padilla, D., Beringue, V., Espinosa, J.C., et al. Sheep and goat BSE propagate more efficiently than cattle BSE in human PrP transgenic mice. (2011) PLoS Pathog 7(3): e1001319.

Pubmed $\mid$ Crossref $\mid$ Others

5. Prusiner, S.B. Prions. (1998) Proc Natl Acad Sci U S A 95(23):

13363-13383.

Pubmed $\mid$ Crossref $\mid$ Others

6. Konold, T., Moore, S.J., Bellworthy, S.J., et al. Evidence of effective scrapie transmission via colostrum and milk in sheep. (2013) BMC Vet Res 9: 99.

Pubmed $\mid$ Crossref $\mid$ Others
7. Konold, T., Thorne, L., Simmons, H.A., et al. Evidence of scrapie transmission to sheep via goat milk. (2016) BMC Vet Res 12: 208.

Pubmed $\mid$ Crossref $\mid$ Others

8. Lacroux, C., Simon, S., Benestad, S.L., et al. Prions in milk from ewes incubating natural scrapie. (2008) PLoS Pathog 4(12): e1000238. Pubmed $\mid$ Crossref $\mid$ Others

9. Ligios, C., Cancedda, M.G., Carta, A., et al. Sheep with scrapie and mastitis transmit infectious prions through the milk. (2011) J virol 85(2): 1136-1139.

Pubmed | Crossref $\mid$ Others

10. Ciric, D., Rezaei, H. Biochemical insight into the prion protein family. (2015) Front Cell Dev Biol 3: 5.

Pubmed $\mid$ Crossref $\mid$ Others

11. Sakudo, A., Onodera, T., 2014. Prion protein (PrP) gene-knockout cell lines: insight into functions of the PrP. Front Cell Dev Biol 2, 75.

Pubmed $\mid$ Crossref $\mid$ Others

12. Jarosz-Griffiths, H.H., Noble, E., Rushworth, J.V., et al. Amyloid-beta Receptors: The Good, the Bad, and the Prion Protein. (2016) The Journal of biological chemistry 291, 3174-3183.

Pubmed $\mid$ Crossref $\mid$ Others

13. Xia, M., Cheng, X., Yi, R., et al. The Binding Receptors of Abeta: an Alternative Therapeutic Target for Alzheimer's Disease. (2016) Molecular neurobiology 53: 455-471.

Pubmed $\mid$ Crossref $\mid$ Others

14. Bueler, H., Aguzzi, A., Sailer, A., et al. Mice devoid of PrP are resistant to scrapie. (1993) Cell 73(7): 1339-1347.

Pubmed $\mid$ Crossref $\mid$ Others

15. Mallucci, G., Dickinson, A., Linehan, J., et al. Depleting neuronal $\mathrm{PrP}$ in prion infection prevents disease and reverses spongiosis. (2003) Science 302(5646): 871-874.

Pubmed $\mid$ Crossref $\mid$ Others

16. Saa, P., Cervenakova, L. Protein misfolding cyclic amplification (PMCA): Current status and future directions. (2015) Virus Res 207: 47-61.

Pubmed $\mid$ Crossref $\mid$ Others

17. Seuberlich, T., Heim, D., Zurbriggen, A. Atypical transmissible spongiform encephalopathies in ruminants: a challenge for disease surveillance and control. (2010) J Vet Diagn Invest 22(6): 823-842.

Pubmed $\mid$ Crossref $\mid$ Others

18. Aguzzi, A., Polymenidou, M. Mammalian prion biology: one century of evolving concepts. (2004) Cell 116(2): 313-327.

Pubmed $\mid$ Crossref $\mid$ Others

19. Gough, K.C., Maddison, B.C. Prion transmission: Prion excretion and occurrence in the environment. (2010) Prion 4: 275-282.

Pubmed $\mid$ Crossref $\mid$ Others

20. Moda, F., Gambetti, P., Notari, S., et al. Prions in the urine of patients with variant Creutzfeldt-Jakob disease. (2014) The New England journal of medicine 371: 530-539.

Pubmed $\mid$ Crossref $\mid$ Others

21. Xu, S., Reuter, T., Gilroyed, B.H., et al. Biodegradation of specified risk material and fate of scrapie prions in compost. (2013) J Environ Sci Health A Tox Hazard Subst Environ Eng 48(1): 26-36.

Pubmed $\mid$ Crossref $\mid$ Others

22. EFSA, B.P.E.P.o.B.H. Scientific Opinion on BSE risk in bovine intestines and mesentery. (2014) EFSA Journal 12: 3554(3598PP).

Pubmed $\mid$ Crossref $\mid$ Others

23. Ducrot, C., Arnold, M., de Koeijer, A., et al. Review on the epidemiology and dynamics of BSE epidemics. (2008) Veterinary research 39: 15 .

Pubmed | Crossref $\mid$ Others

24. EFSA, P.o.B.H.B. TSE in small Ruminants-European Commission. (2010) EFSA Journal 8: 1875-1892.

Pubmed $\mid$ Crossref $\mid$ Others

25. Gough, K.C., Baker, C.A., Taema, M., et al. In vitro amplification of prions from milk in the detection of subclinical infections. (2009) Prion 3: 236-239.

Pubmed | Crossref $\mid$ Others 
26. Franscini, N., El Gedaily, A., Matthey, U., et al. Prion protein in milk. (2006) PloS one 1:e71.

Pubmed | Crossref $\mid$ Others

27. Maddison, B.C., Whitelam, G.C., Gough, K.C. Cellular prion protein in ovine milk. (2007) Biochem Biophys Res Commun 353(1): 195199.

Pubmed $\mid$ Crossref $\mid$ Others

28. Maddison, B.C., Baker, C.A., Rees, H.C., et al. Prions are secreted in milk from clinically normal scrapie-exposed sheep. (2009) J Virol 83(16): 8293-8296.

Pubmed $\mid$ Crossref $\mid$ Others

29. Zhu, L.Y., Cong, F.H., Li, C.H., et al. Effect of defat and staining on the testing of somatic cell count in raw milk. (2008) Dairy Industry 36: 33-35.

Pubmed $\mid$ Crossref $\mid$ Others

30. WJ, C., XQ, Y., P, T., et al. Improvement of a rapid determination method of somatic cells count in milk. (2007) J Chinese Institute of Food Sci Technol 7(): 114-118.

Pubmed $\mid$ Crossref $\mid$ Others

31. Didier, A., Dietrich, R., Steffl, M., et al. Cellular prion protein in the bovine mammary gland is selectively expressed in active lactocytes. (2006) J Histochemistry and cytochemistry : official journal of the Histochemistry Society 54(11): 1255-1261.

Pubmed $\mid$ Crossref $\mid$ Others

32. Didier, A., Gebert, R., Dietrich, R., et al. Cellular prion protein in mammary gland and milk fractions of domestic ruminants. (2008) Biochem Biophys Res Commun 369(3): 841-844.

Pubmed | Crossref $\mid$ Others

33. Heeschen, W.H. BSE: milk and risk potential? DTW. (2002) Dtsch Tierarztl Wochenschr 109(8): 350-353.

Pubmed $\mid$ Crossref $\mid$ Others

34. Tyshenko, M.G. Bovine spongiform encephalopathy and the safety of milk from Canadian dairy cattle. (2007) Vet Rec 160(7): 215-218.

Pubmed | Crossref | Others

35. Taylor, D.M., Ferguson, C.E., Bostock, C.J., et al. Absence of disease in mice receiving milk from cows with bovine spongiform encephalopathy. (1995) Vet Rec 136(23): 592.

Pubmed $\mid$ Crossref $\mid$ Others

36 . Vetrugno, V. Safety of milk and milk derivatives in relation to BSE: the lactoferrin example. (2004) Biometals : an international journal on the role of metal ions in biology, biochemistry, and medicine 17(3): 353-356.

Pubmed $\mid$ Crossref $\mid$ Others

37. Zhuang, L.P., Tao, L.M., Wang, Z.L. Progress on tissue infectivity of TSEs. (2006) Chinese Journal of Zoonoses 22(): 1078-1082.

Pubmed $\mid$ Crossref $\mid$ Others

38. Everest, S.J., Thorne, L.T., Hawthorn, J.A., et al. No abnormal prion protein detected in the milk of cattle infected with the bovine spongiform encephalopathy agent. (2006) J Gen Virol 87: 2433-2441.

Pubmed $\mid$ Crossref $\mid$ Others

39. Bradley, R.. BSE risks for humans consuming beef and beef products: how any risks are managed. (2003) Vet Res Comm 27 Suppl 1: 15-23.

Pubmed | Crossref $\mid$ Others

40. van Keulen, L.J., Schreuder, B.E., Meloen, R.H., et al. Immunohistochemical detection of prion protein in lymphoid tissues of sheep with natural scrapie. (1996) J Clin Microbiol 34(5): 1228-1231.

Pubmed $\mid$ Crossref $\mid$ Others
41. Ligios, C., Sigurdson, C.J., Santucciu, C., et al. PrPSc in mammary glands of sheep affected by scrapie and mastitis. (2005) Nat med 11(11): 1137-1138.

Pubmed $\mid$ Crossref $\mid$ Others

42. Hoinville, L.J., Tongue, S.C., Wilesmith, J.W. Evidence for maternal transmission of scrapie in naturally affected flocks. (2010) Prev Vet Med 93(2-3): 121-128.

Pubmed $\mid$ Crossref $\mid$ Others

43. Bruce, M.E., Will, R.G., Ironside, J.W., et al. Transmissions to mice indicate that 'new variant' CJD is caused by the BSE agent. (1997) Nature 389(6650): 498-501.

Pubmed $\mid$ Crossref $\mid$ Others

44. Collinge, J., Sidle, K.C., Meads, J., et al. Molecular analysis of prion strain variation and the aetiology of 'new variant' CJD. (1996) Nature 383(6602): 685-690.

Pubmed $\mid$ Crossref $\mid$ Others

45. Konold, T., Moore, S.J., Bellworthy, S.J., et al. Evidence of scrapie transmission via milk. (2008) BMC Vet Res 4, 14.

Pubmed $\mid$ Crossref $\mid$ Others

46. Journal, E. Opinion of the Scientific Panel on Biological Hazards onthe human and animal exposure risk related to Transmissible SpongiformEncephalopathies (TSEs) from milk and milk products derived from small rumi-nants. (2008) (Question No EFSA-Q-2008-310), 1-3. Pubmed $\mid$ Crossref $\mid$ Others

47. Castilla, J., Gonzalez-Romero, D., Saa, P., et al. Crossing the species barrier by $\operatorname{PrP}(\mathrm{Sc})$ replication in vitro generates unique infectious prions. (2008) Cell 134(5): 757-768.

Pubmed | Crossref $\mid$ Others

48. Green, K.M., Castilla, J., Seward, T.S., et al. Accelerated high fidelity prion amplification within and across prion species barriers. (2008) PLoS Pathog 4(8): e1000139.

Pubmed | Crossref $\mid$ Others

49. Elsen, J.M., Amigues, Y., Schelcher, F., et al. Genetic susceptibility and transmission factors in scrapie: detailed analysis of an epidemic in a closed flock of Romanov. (1999) Archives of virology 144(3): 431445.

Pubmed $\mid$ Crossref $\mid$ Others

50. Ingravalle, F., Abete, M.C., Crescio, M.I., et al. Detection of animal-derived proteins in feedstuffs in Italy: a reproducibility study. (2007) J food prot 70(4): 986-990.

Pubmed $\mid$ Crossref $\mid$ Others

51. Feligini, M., Bongioni, G., Brambati, E., et al. Real-time qPCR is a powerful assay to estimate the $171 \mathrm{R} / \mathrm{Q}$ alleles at the PrP locus directly in a flock's raw milk: a comparison with the targeted next-generation sequencing. (2014) J Virol Methods 207: 210-214.

Pubmed $\mid$ Crossref $\mid$ Others

52. Cheng, G.L., Jiang, X.X., Zhao, H.L., et al. The hazard and control method for large number of cells in cow milk. (2009) Animal Husbandry and Feed Science 30: 65-66.

Pubmed $\mid$ Crossref $\mid$ Others

53. Wu, W.Z., Wang, X.Q., Wang, J.J. Progress in proteome research of breast milk. (2009) Chinese Journal of Animal Nutrition 21: 809-815. Pubmed $\mid$ Crossref $\mid$ Others

54. Guan, F., Pan, L., Shi, G.Q. Research progress on genetic diversity of sheep PRNP and resistance breeding. (2009) Hereditas (Beijing) 31(2): 137-141.

Pubmed $\mid$ Crossref $\mid$ Others

55. Guan, F., Pan, L., Shi, G.Q., et al. The polymorphism of bovine PRNP and resistance. (2008) Grass Feeding Livestock 7-10.

Pubmed $\mid$ Crossref $\mid$ Others
Online ISSN: 2377-0619

Journal Title: International Journal Food and Nutritional Science Journal Short Name: Int J Food Nutr Sci
Ommega Online Publishers

E-mail: editor.foodscience@ommegaonline.com

Website: www.ommegaonline.org 